\title{
Qualitative Analysis of Traditional Italian Dishes: FTIR Approach
}

\author{
Alessandra Durazzo ${ }^{1, *}$, Johannes Kiefer ${ }^{2}{ }^{\mathbb{D}}$, Massimo Lucarini ${ }^{1}$, Emanuela Camilli ${ }^{1}$, \\ Stefania Marconi ${ }^{1}$, Paolo Gabrielli ${ }^{1}$, Altero Aguzzi ${ }^{1}$, Loretta Gambelli ${ }^{1}$, Silvia Lisciani ${ }^{1}$ (i) \\ and Luisa Marletta ${ }^{1}$ \\ 1 CREA Research Centre for Food and Nutrition, Via Ardeatina 546, 00178 Rome, Italy; \\ massimo.lucarini@crea.gov.it (M.L.); emanuela.camilli@crea.gov.it (E.C.); stefania.marconi@crea.gov.it (S.M.); \\ paolo.gabrielli@crea.gov.it (P.G.); altero.aguzzi@crea.gov.it (A.A.); loretta.gambelli@crea.gov.it (L.G.); \\ silvia.lisciani@crea.gov.it (S.L.); luisa.marletta@crea.gov.it (L.M.) \\ 2 Technische Thermodynamik, Universität Bremen, Badgasteiner Str. 1, 28359 Bremen, Germany; \\ jkiefer@uni-bremen.de \\ * Correspondence: alessandra.durazzo@crea.gov.it; Tel.: +39-065-149-4430
}

Received: 29 September 2018; Accepted: 5 November 2018; Published: 9 November 2018

check for updates

\begin{abstract}
Italian cuisine and its traditional recipes experience an ever-increasing popularity around the world. The "Integrated Approach" is the key to modern food research and the innovative challenge for analyzing and modeling agro-food systems in their totality. The present study aims at applying and evaluating Fourier Transformed Infrared (FTIR) spectroscopy for the analysis of complex food matrices and food preparations. Nine traditional Italian recipes, including First courses, One-dish meals, Side courses, and Desserts, were selected and experimentally prepared. Prior to their analysis via FTIR spectroscopy, the samples were homogenized and lyophilized. The IR spectroscopic characterization and the assignment of the main bands was carried out. Numerous peaks, which correspond to functional groups and modes of vibration of the individual components, were highlighted. The spectra are affected by both the preparation procedures, the cooking methods, and the cooking time. The qualitative analysis of the major functional groups can serve as a basis for a discrimination of the products and the investigation of fraud. For this purpose, the FTIR spectra were evaluated using Principal Component Analysis (PCA). Our results show how the utilization of vibrational spectroscopy combined with a well-established chemometric data analysis method represents a potentially powerful tool in research linked to the food sector and beyond. This study is a first step towards the development of new indicators of food quality.
\end{abstract}

Keywords: FTIR-ATR; traditional Italian recipes; chemometrics; PCA

\section{Introduction}

Currently, food research is focusing not only on the chemical characteristics and functions of individual foods and/or food components, but is also aimed at understanding their combination in dishes, meals, and diets for a more complete and real assessment of their nutritional impact. In fact, studies on the interactions between individual food components and/or between the different ingredients of cooked and composite dishes seem to play a greater role in the concept of "food synergy" and in reconsidering the total food matrix as a variable of health interest [1].

Italian cuisine and its traditional recipes represent a great legacy of tradition and culture for the country becoming more and more popular all over the world for its great quality, abundance, and variety of food preparations. The Italian culinary traditions are typically Mediterranean, based on cereals, vegetables, fruit, fish, and, in particular, olive oil. Strongly influenced by gastronomic traditions, 
history, local availability, and seasonality, the typical Italian foods and traditional recipes once were closely linked to the production area and were mostly consumed locally [2]. Today, they represent a real heritage and are part of the national food distribution network contributing to the economic and cultural improvement of the entire country. In addition, traditional knowledge passed on from generation to generation and held by local communities, including the ancient practices of the preparation and conservation of the foods and sustainable and natural resources, often played an integral role in achieving sustainable development goals [3].

Despite this, the traditional dishes remain an integral part of a nation's culture that is worth investigation. This needs to consider that the current Italian eating habits are part of the Mediterranean diet and its variants, although they are influenced by the globalization of the market and the changes in lifestyle. Nevertheless, modern Italian cuisine seems to fit well with the Italian culinary traditions [4].

A significant fraction of the dietary intake includes mixed dishes usually based on multiple ingredients/foods. They can be prepared at home or at a restaurant, or they can represent industrially processed foods. To preserve the cultural elements by providing the related dietary information, many researchers have paid special attention to the study of the nutritional characteristics of traditional foods and recipes over the last decade [5-10]; traditional foods are in fact key elements in the dietary patterns of a country. Ramdath et al. [7] have studied the nutritional composition of commonly consumed dishes in Trinidad to determine the associations between diet and the risk of chronic diseases. The aim was to improve the dietary quality among the population. Costa et al. [9] and Lombardi Boccia e Marletta [5] emphasized the importance of knowing the nutritional composition. Their aim was to contribute to the promotion of the local biodiversity and sustainable diets by maintaining healthy dietary patterns within local cultures. They used several traditional foods from the Black Sea area and from Italy as a case study. However, detailed characteristics of traditional full dishes are usually not included in the national food composition databases, which are commonly used to make dietary recommendations. Therefore, it is difficult to make a meaningful comparison between what we eat and the recommendations made. Costa et al. [8] and Durazzo et al. [10] made attempts to include such a holistic approach to food and food analysis.

There have been large research projects in this area, see, for example, the EuroFIR project (www.eurofir.net). For instance, Guerrero et al. [11] have identified the main different aspects that European consumers seem to perceive when thinking about traditional food products: habits and nature, origin and locality, processing and elaboration, and sensory properties. The authors concluded that when innovations are applied to traditional food products, their degree of acceptance is strongly dependent on the product and on the type of innovation [11].

The "Integrated Approach" is the key to modern food research and the innovative challenge for analyzing and modelling agro-food systems in their totality [12,13]. As is generally true in the food sector, the recent developments and advancements in instrumentation as well as chemometric pattern recognition techniques, including principal component analysis (PCA), hierarchical cluster analysis, and partial least squares regression (PLSR), have amplified the range of the IR spectroscopy applications to food products. Thus, the IR spectra can be used to identify or differentiate between samples [14]. The list of applications includes evaluating and determining components [15,16], monitoring contaminants and adulterants [17,18], classification [19,20], discrimination [21,22], authentication [23,24], etc. In this context, the review of Rodriguez-Saona and Allendorf [25] is worth mentioning. It gives an overview of the main applications of near infrared (NIR) and mid-infrared (MIR) spectroscopy for the rapid authentication and detection of adulteration of food.

FTIR spectroscopy coupled with multivariate statistical data analysis has an enormous potential to facilitate the measurement of quality attributes. Generally, the application of statistical methods in food science allows the highlighting of effective trends, to study and investigate relationships, and to draw conclusions from experimental data [26]. Chemometrics is often referred to as the discipline that uses mathematical and statistical methods to obtain relevant information from collected data [27]. From the chemometric analysis of FTIR spectra, a large amount of information can be derived [28]. 
FTIR spectroscopy represents a rapid, less destructive, and high-throughput method for the analysis of food products. It provides simplified handling and it enables the samples being examined directly in their original state. The FTIR method has successfully been used for food composition determination, food distinction/differentiation, and food authentication in several food matrices [29,30]. Karoui et al. [31] described the application of IR spectroscopy and chemometric data analysis to different food groups: dairy products, meat and meat products, fish, edible oils, cereals and cereal products, sugar and honey, fruit and vegetable, and coffee. Their focus was on the analysis of intact food systems and the exploration of their molecular structure-quality relationships. Franca and Olivera [32] gave a critical overview of the application of FTIR in food processing and engineering. However, only a few studies have used FTIR spectroscopy to analyze composite dishes [31,32]. To make an important step beyond the published work, the present study aims at applying and evaluating FTIR spectroscopy for the analysis of some Italian complex food matrices and food preparations. The objectives include (1) qualitative analysis of the major functional groups and (2) discrimination analysis by applying PCA to the FTIR data set in order to test whether or not a classification is possible. In previous studies [10,33], the focus was on traditional analytical methods to determine the proximate composition and the dietary intake evaluation. In contrast, the present work aims at applying an integrated analytical approach for classification of these dishes as reported for the case study of the Béchamel sauce [13].

\section{Materials and Methods}

\subsection{Selection of Recipes and Experimental Preparations}

Nine traditional Italian recipes, including First courses, One-dish meals, Side courses, and Desserts, as shown in Table 1, were selected and experimentally prepared $[10,33]$ in a dedicated lab-kitchen following a validated and standardized protocol developed within the EuroFIR Network [34].

Table 1. Ingredients, preparation procedures, cooking methods, and cooking times of some Italian traditional dishes.

\begin{tabular}{|c|c|c|c|c|}
\hline Original Name & Food Name & Ingredients (g/100 g) & $\begin{array}{l}\text { Preparation Procedures and } \\
\text { Cooking Methods }\end{array}$ & $\begin{array}{l}\text { Timing } \\
\text { (min.) }\end{array}$ \\
\hline \multicolumn{5}{|c|}{ First Courses } \\
\hline $\begin{array}{l}\text { Spaghetti alle } \\
\text { vongole }[10,33]\end{array}$ & $\begin{array}{l}\text { Spaghetti } \\
\text { with clams }\end{array}$ & $\begin{array}{l}\text { Spaghetti (48.8), clams without } \\
\text { shell (44.8), extra virgin olive oil } \\
\text { (3.3), garlic (1.4), salt (0.4), parsley } \\
\text { chopped (1.2), chili pepper (0.1). }\end{array}$ & $\begin{array}{l}\text { Boil the spaghetti in salted water. Fry the } \\
\text { garlic and pepper in olive oil in a pan, } \\
\text { then add the clams and leave on the heat } \\
\text { until the valves open. Add cooked spaghetti } \\
\text { and parsley. }\end{array}$ & 16 \\
\hline $\begin{array}{c}\text { Pasta alla } \\
\text { amatriciana [10] }\end{array}$ & $\begin{array}{l}\text { Amatriciana } \\
\text { pasta }\end{array}$ & $\begin{array}{l}\text { Pasta (tortiglioni) (37.5), diced } \\
\text { tomatoes (37.5), Amatrice cheek } \\
\text { lard diced (16), Roman Pecorino } \\
\text { cheese PDO (hard cheese from } \\
\text { sheep milk) (7.5), extra virgin } \\
\text { olive oil (1.1), salt (0.3), } \\
\text { chili pepper (0.1). }\end{array}$ & $\begin{array}{l}\text { Cut the cheek lard into strips and brown it in } \\
\text { a pan with olive oil and chili pepper. Add the } \\
\text { tomato and salt, simmer for about } 20 \mathrm{~min} \text {. } \\
\text { Meanwhile, boil the pasta in salted water, } \\
\text { then drain it and toss with the sauce, and, } \\
\text { lastly, add the Pecorino cheese. }\end{array}$ & 25 \\
\hline $\begin{array}{c}\text { Pasta alla } \\
\text { carbonara [10] }\end{array}$ & $\begin{array}{l}\text { Carbonara } \\
\text { Pasta }\end{array}$ & $\begin{array}{l}\text { Short pasta (47.3), bacon cubes } \\
\text { (20.3), Roman Pecorino cheese } \\
\text { PDO (hard cheese from sheep } \\
\text { milk) (13.6), eggs (16.6), } \\
\text { extra virgin olive oil (1.4), } \\
\text { salt (0.4), black pepper }(0.4) \text {. }\end{array}$ & $\begin{array}{l}\text { Mix eggs, Pecorino cheese, salt, and pepper } \\
\text { to become a creamy mixture. Meanwhile, } \\
\text { brown the bacon in a pan. Boil the pasta in } \\
\text { salted water, drain and add it to the bacon, } \\
\text { and then remove the pan from the heat. } \\
\text { Finally, pour the egg mixture onto the pasta } \\
\text { and mix until the cream thickens slightly. }\end{array}$ & 13 \\
\hline
\end{tabular}


Table 1. Cont.

\begin{tabular}{|c|c|c|c|c|}
\hline Original Name & Food Name & Ingredients (g/100 g) & $\begin{array}{l}\text { Preparation Procedures and } \\
\text { Cooking Methods }\end{array}$ & $\begin{array}{l}\text { Timing } \\
\text { (min.) }\end{array}$ \\
\hline \multicolumn{5}{|c|}{ One-dish meals } \\
\hline $\begin{array}{l}\text { Parmigiana di } \\
\text { melanzane [33] }\end{array}$ & $\begin{array}{l}\text { Eggplant } \\
\text { parmesan }\end{array}$ & $\begin{array}{l}\text { Eggplants (49.8), vegetable oil } \\
\text { (for frying), extra virgin olive oil } \\
(0.5) \text {, diced tomatoes ( } 35.7) \text {, } \\
\text { two garlic cloves, mozzarella } \\
\text { cheese (uncured cheese) }(9.6), \\
\text { Parmigiano Reggiano cheese PDO } \\
\text { (hard cheese) (4.2), leaves of basil } \\
(0.1) \text {, salt }(0.1) .\end{array}$ & $\begin{array}{l}\text { Cut the eggplants into } 1 \mathrm{~cm} \text { thick slices. } \\
\text { Fry the slices for about } 5 \text { min in boiling oil, } \\
\text { remove and drain on kitchen paper. Fry the } \\
\text { garlic in pan with olive oil, then add the } \\
\text { tomato. Simmer the sauce over medium heat. } \\
\text { Cut the mozzarella into small cubes. Sprinkle } \\
\text { the bottom of a baking pan with the tomato } \\
\text { sauce. Make layers of fried eggplants, tomato } \\
\text { sauce, Parmigiano Reggiano cheese, } \\
\text { and mozzarella. Continue until the } \\
\text { ingredients are exhausted, and finish with } \\
\text { the sauce and Parmigiano Reggiano cheese. } \\
\text { Bake in a preheated static oven at } 180^{\circ} \mathrm{C} \text {. }\end{array}$ & 25 \\
\hline $\begin{array}{l}\text { Gâteau di patate } \\
{[10,33]}\end{array}$ & Potato flan & $\begin{array}{l}\text { Baked potatoes crushed (61.5), } \\
\text { ham ( } 7.9), \text { mozzarella cheese } \\
\text { (uncured cheese) (6.7), scamorza } \\
\text { cheese (semisoft cheese) (6.6), } \\
\text { Parmigiano Reggiano cheese PDO } \\
\text { (hard cheese) (5.3), butter (1.3), } \\
\text { milk ( } 2.3), \text { pepper (0.01), nutmeg } \\
\text { (0.01), eggs (6.9), salt (0.1), } \\
\text { bread crumbs (1.1). }\end{array}$ & $\begin{array}{l}\text { Finely crush the boiled potatoes. Mix the } \\
\text { potatoes in a large bowl with butter, milk, } \\
\text { and Parmigiano Reggiano cheese, and cool } \\
\text { the mixture. Add the eggs, the mozzarella, } \\
\text { and the diced scamorza, the ham cooked in } \\
\text { strips, the salt, the pepper, and the nutmeg. } \\
\text { Pour the mixture in the baking dish and } \\
\text { sprinkle breadcrumbs on the well-flat surface. } \\
\text { Bake in a traditional oven at } 160^{\circ} \mathrm{C} \text {. Lightly } \\
\text { grate the surface. }\end{array}$ & 20 \\
\hline \multicolumn{5}{|c|}{ Side courses } \\
\hline $\begin{array}{l}\text { Carciofi alla } \\
\text { romana }[10,33]\end{array}$ & $\begin{array}{l}\text { Roman } \\
\text { artichokes }\end{array}$ & $\begin{array}{l}\text { "Roman" artichokes PGI (74.4), } \\
\text { chopped mint }(0.1) \text {, chopped } \\
\text { parsley (2), finely chopped garlic } \\
(0.6) \text {, extra virgin olive oil }(6.1) \text {, } \\
\text { salt }(0.4) \text {, water }(42.5) \text {, pepper } \\
(0.05) .\end{array}$ & $\begin{array}{l}\text { Stuff the artichokes with mint, parsley, garlic, } \\
\text { pepper, and salt, and place them in a pan. } \\
\text { Add water and olive oil, and stew over } \\
\text { medium heat. }\end{array}$ & 20 \\
\hline \multicolumn{5}{|c|}{ Desserts } \\
\hline $\begin{array}{c}\text { Pan di Spagna } \\
{[10,33]}\end{array}$ & Sponge cake & $\begin{array}{l}\text { Eggs (49.6), sugar (27.1), } \\
\text { flour (22.6), salt }(0.04) .\end{array}$ & $\begin{array}{l}\text { Beat the egg yolks with the sugar in a bowl } \\
\text { until pale and fluffy. Whisk the egg whites to } \\
\text { stiff peaks in another bowl then gently pour } \\
\text { into the egg yolks mixture. Add a little at a } \\
\text { time to the sifted flour. Pour the mixture into } \\
\text { the mold and bake in a traditional oven at } \\
180^{\circ} \mathrm{C} \text {. }\end{array}$ & 20 \\
\hline $\begin{array}{c}\text { Torta di mele } \\
\qquad[33]\end{array}$ & Apple pie & $\begin{array}{l}\text { Apples cultivar "Renetta" (37.7), } \\
\text { sugar (15), wheat flour (18), butter } \\
\text { (9.3), eggs (9.2), whole milk (7.5), } \\
\text { baking powder (1), vanilla (0.03), } \\
\text { grated lemon peel (0.2), lemon } \\
\text { juice (2.4). }\end{array}$ & $\begin{array}{l}\text { Whip the butter in a bowl with the } \\
\text { granulated sugar until you get a frothy } \\
\text { mixture, add the eggs, one at a time, the milk, } \\
\text { and the grated lemon peel. Add the sifted } \\
\text { flour and baking powder, stirring with } \\
\text { a spatula, and add a pinch of salt. Peel the } \\
\text { apples, cut them into slices that are not too } \\
\text { large. Pour the mixture into a properly } \\
\text { greased and floured mold, leveling well. } \\
\text { Carefully place the apple slices on top of the } \\
\text { dough. Bake in a preheated oven at } 180^{\circ} \mathrm{C} \text {. }\end{array}$ & 30 \\
\hline Pastiera [33] & Pastiera cake & $\begin{array}{l}\text { Shortcrust pastry (31.5), ricotta } \\
\text { cheese (soft cheese from sheep } \\
\text { milk) (22.3), sugar (16.7), wheat } \\
\text { cooked canned (13.4), whole milk } \\
\text { (3.4), eggs (10.1), butter (1), citron } \\
\text { candied (1.2), orange flower water } \\
\text { (0.3) vanilla (0.02). }\end{array}$ & $\begin{array}{l}\text { Melt the butter in a pan with the grated } \\
\text { lemon and orange peels. Add the cooked } \\
\text { wheat and milk, simmer until it becomes } \\
\text { a cream. Allow to cool. In a bowl, mix the } \\
\text { ricotta with the sugar and the egg yolks, } \\
\text { add to the mixture the cream of cooked } \\
\text { wheat, the candied citron, orange flower } \\
\text { water, and vanillin, and finally the beaten egg } \\
\text { whites. Roll out the pastry and place it in } \\
\text { a buttered cake tin. Pour the mixture and } \\
\text { decorate with crossed strips of shortcrust } \\
\text { pastry. Bake in a preheated oven at } 180^{\circ} \mathrm{C} \\
\text { until it becomes a nice amber color. }\end{array}$ & 40 \\
\hline
\end{tabular}


In detail, for every selected recipe, a document collection was carried out from the most popular and traditional cookbooks in Italy (Il cucchiaio d'argento; La cucina italiana, etc). A "standard recipe" was identified and one "preparation protocol" was elaborated to just establish ingredients, amounts, preparation, and cooking techniques (time, temperature, utensils, etc.). The sampling plan considered the collection of single ingredients in different retail stores and supermarkets. Ingredients were purchased by collecting the main food brands and/or varieties of the same product. Each individual food brand (primary sample) for every ingredient (secondary sample) was properly weighed and then combined to make an aggregate sample (pool) before using it for the preparation of the final dish (laboratory sample). The dish was assembled and cooked by trained personnel according to the "preparation protocol" of the "standard recipe". For this purpose, common household methods and utensils were used. Two independent batches (about $2 \mathrm{~kg}$ for each composite dish) were produced in different periods. After cooking, the prepared dishes were weighed once more. Then, they were homogenized, frozen at $-30{ }^{\circ} \mathrm{C}$, and then lyophilized for the FTIR analysis. The lyophilization guarantees the homogenization and uniformity of the samples. In addition, this method allowed an optimal storage to protect the sample from oxidation, contamination, or other potential effects $[34,35]$.

\subsection{FTIR-ATR Analysis}

The FTIR spectra were recorded on a Nicolet iS10 FT-IR spectrometer equipped with a diamond crystal cell for attenuated total reflection (ATR) operation. The spectra were acquired (32 scans per sample or background) in the range of $4000-650 \mathrm{~cm}^{-1}$ at a nominal resolution of $4 \mathrm{~cm}^{-1}$. The spectra were corrected using the background spectrum of air. The analysis was carried out at room temperature. For a measurement, a lyophilized sample was placed onto the surface of the ATR crystal. Before acquiring a spectrum, the ATR crystal was carefully cleaned with wet cellulose tissue and dried using a flow of nitrogen gas. The cleaned crystal was checked spectrally to ensure that no residue was retained from the previous sample. The spectrum of every sample was collected 5 times to check the reproducibility and do a statistical analysis. It should be noted that the individual spectra of the same dish varied to some extent, up to variations in the absorbance values of $30 \%$. However, the characteristic signatures remained very similar so that averaged spectra are shown in the following.

\subsubsection{Qualitative Analysis of the Spectra}

As a first step, the FTIR spectra were analyzed with respect to the spectral band positions to identify the signatures of the major functional groups. An assignment of the main bands was carried out by analyzing the acquired spectra and by comparing them with those in the literature.

\subsubsection{Multivariate Analysis of the Spectra}

The application of PCA to the FTIR spectra was carried out in the second step. The evaluation algorithms were implemented in Matlab using the princomp routine. PCA is a purely mathematical and unsupervised procedure, which is aimed at the most meaningful representation of a data set. For this purpose, the dimensionality of the data matrix is reduced and the relevant information is extracted. In a first step, the covariance matrix of the initial data matrix is calculated. Then, the eigenvalues and eigenvectors of this covariance matrix are determined. Thirdly, the eigenvectors are sorted with respect to their variance. The eigenvector with the largest eigenvalue shows the most variance in the data set and is thus called the first principal component (PC1), and so on. In this procedure, the signal variance is a measure for the relevance of the information stored in the data set. The implemented diagonalization of the covariance matrix results in a decomposition of the original data matrix into the loadings and the scores. The scores represent the initial data in the new dimensional space spanned by the principal components. The loadings are the eigenvectors of the matrix. In other words, they represent the contribution of the original data to creating the principal components. Samples 
displayed in the new space show closer positions when they have a strong relationship. The resulting scores plot can be used for a classification of the data set.

In practice, the purpose of unsupervised methods is to find groups of samples, which have related features, to allow their separation into different classes. PCA is the most widespread unsupervised tool in the field of food [36].

\section{Results and Discussion}

\subsection{Qualitative Analysis}

FTIR spectroscopy can be defined as a "fingerprint analytical technique" for the structural identification of compounds considering that no two chemical structures will have the same FTIR spectrum [37]. FTIR provides a characteristic signature of chemical or biochemical substances present in the sample by featuring their molecular vibrations (stretching, bending, and torsions of the chemical bonds) in specific infrared regions.

Figures 1-4 show the FTIR spectra of the experimental preparations, grouped as First Course (Spaghetti alle vongole, Pasta alla amatriciana, Pasta alla carbonara), One-dish meals (Parmigiana di melenzane, Gâteau di patate), Side courses (Carciofi alla romana), and Desserts (Pan di Spagna, Torta di mele, Pastiera).

The spectra contain a multitude of bands that are more or less characteristic of food samples. The spectra are affected by the preparation procedures, the cooking methods, and the cooking time. In the spectra displayed, the specific bands characteristic of the dishes are highlighted and assigned as follows.

The FTIR spectra show bands associated with the main classes of organic molecules. The band at $3289 \mathrm{~cm}^{-1}$ is characteristic of $\mathrm{NH}$ and $\mathrm{OH}$ stretching vibrations. The region of $2923-2853 \mathrm{~cm}^{-1}$ can be assigned to the symmetrical and asymmetric stretching modes of the $\mathrm{CH}_{3}$ and $\mathrm{CH}_{2}$ groups. The $1745 \mathrm{~cm}^{-1}$ band corresponds to the stretching of the $\mathrm{C}=\mathrm{O}$ ester carbonyl or carboxylic acid groups, which are characteristic of fatty acids. The amide I band at $1645 \mathrm{~cm}^{-1}$ results from the $\mathrm{C}=\mathrm{O}$ stretching in the amides I, II, and III, while the amidic band II at $1545 \mathrm{~cm}^{-1}$ originates from the bending vibrations of the N-H groups. The IR region from 1500 to $800 \mathrm{~cm}^{-1}$ is commonly referred to as the "fingerprint" region, which includes bands corresponding to the vibrations of the C-O, C-C, C-H, and C-N bonds [38]. This region is, on the one hand, very rich in information, but, on the other hand, difficult to analyze due to its complexity. This area provides important information about organic compounds, such as sugars, alcohols, and organic acids, present in the sample.

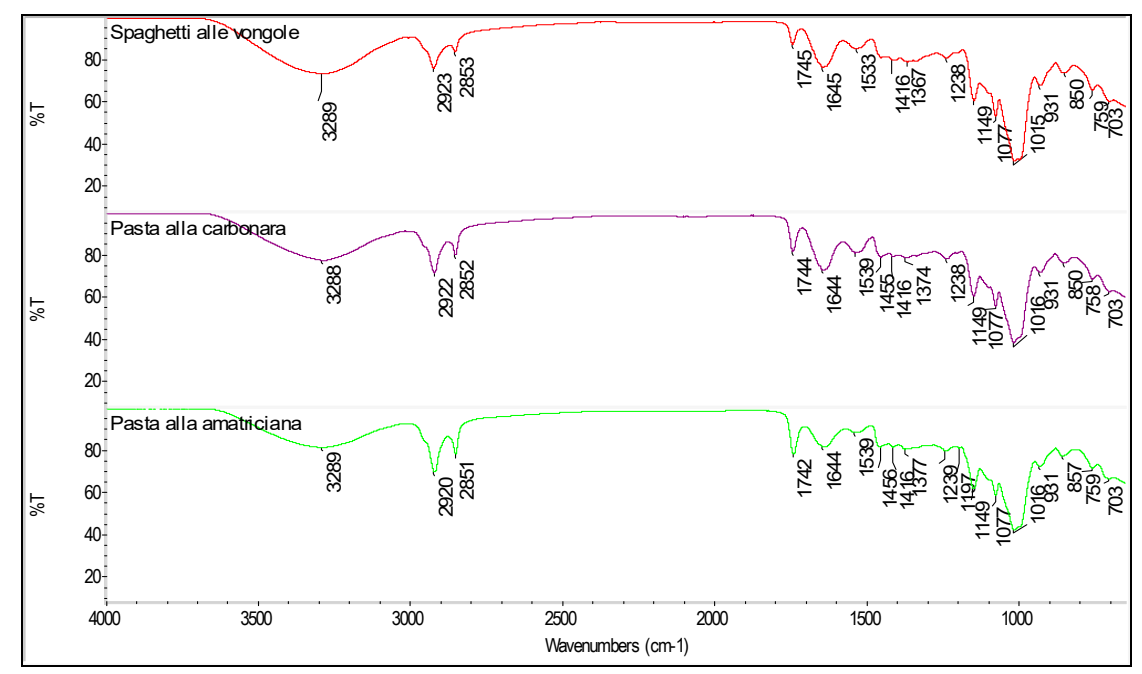

Figure 1. Averaged FTIR spectra of experimental First courses dishes (Spaghetti alle vongole, Pasta alla amatriciana, Pasta alla carbonara) in the mid-infrared region $\left(4000-650 \mathrm{~cm}^{-1}\right)$. 


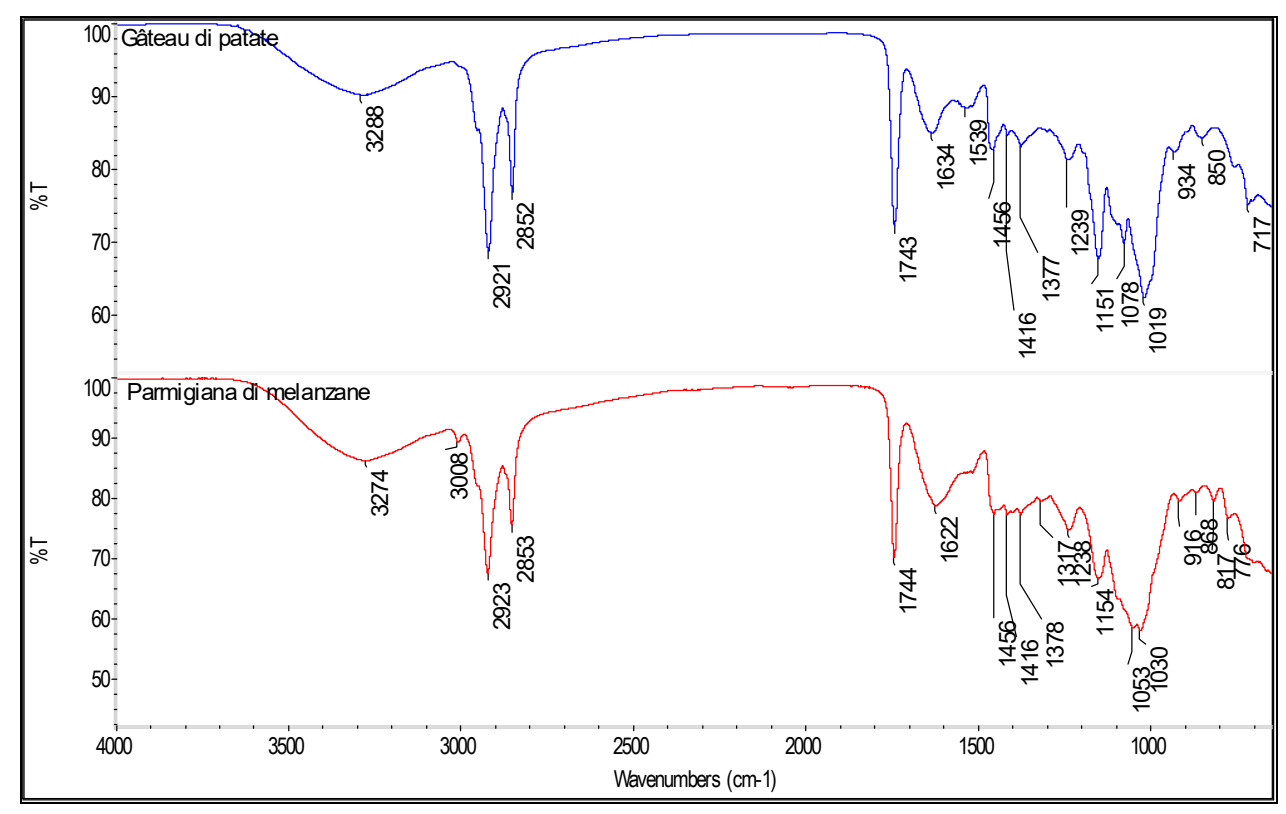

Figure 2. Averaged FTIR spectra of One dish meals (Parmigiana di melanzane, Gâteau di patate) in the mid-infrared region $\left(4000-650 \mathrm{~cm}^{-1}\right)$.

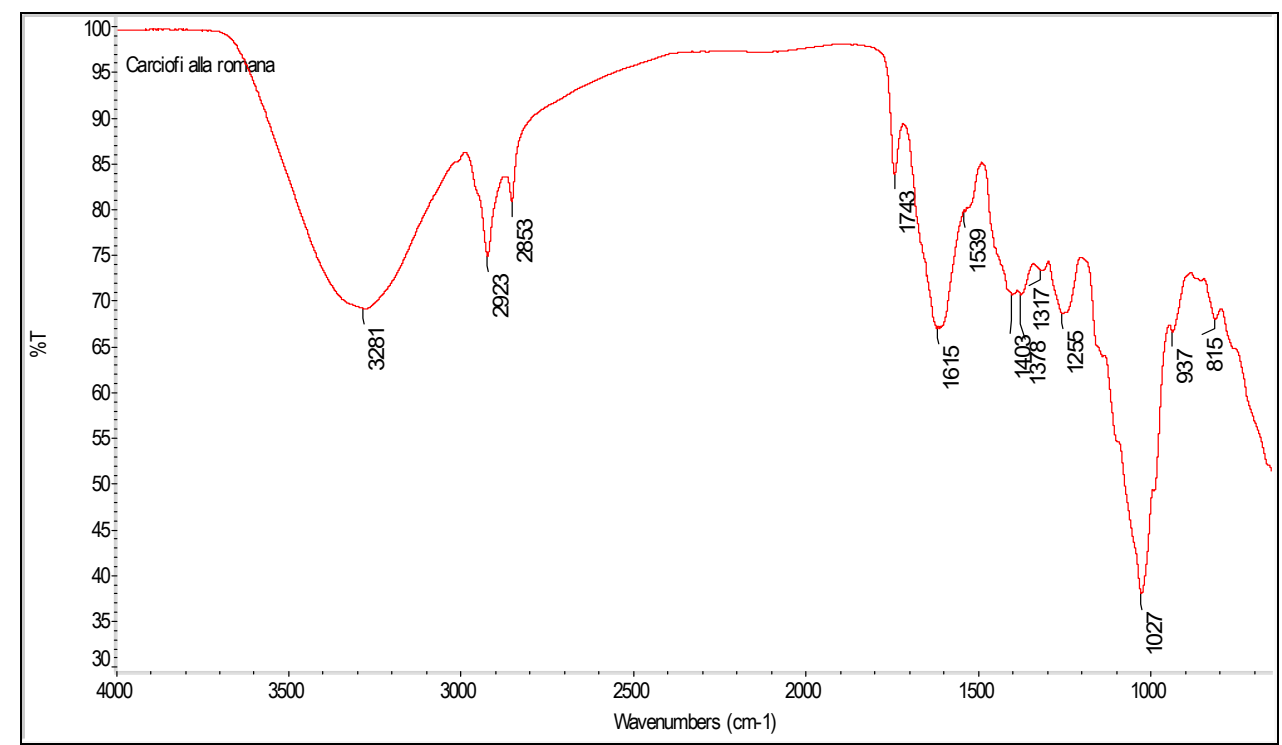

Figure 3. Averaged FTIR spectra of Side courses (Carciofi alla romana) in the mid-infrared region $\left(4000-650 \mathrm{~cm}^{-1}\right)$. 


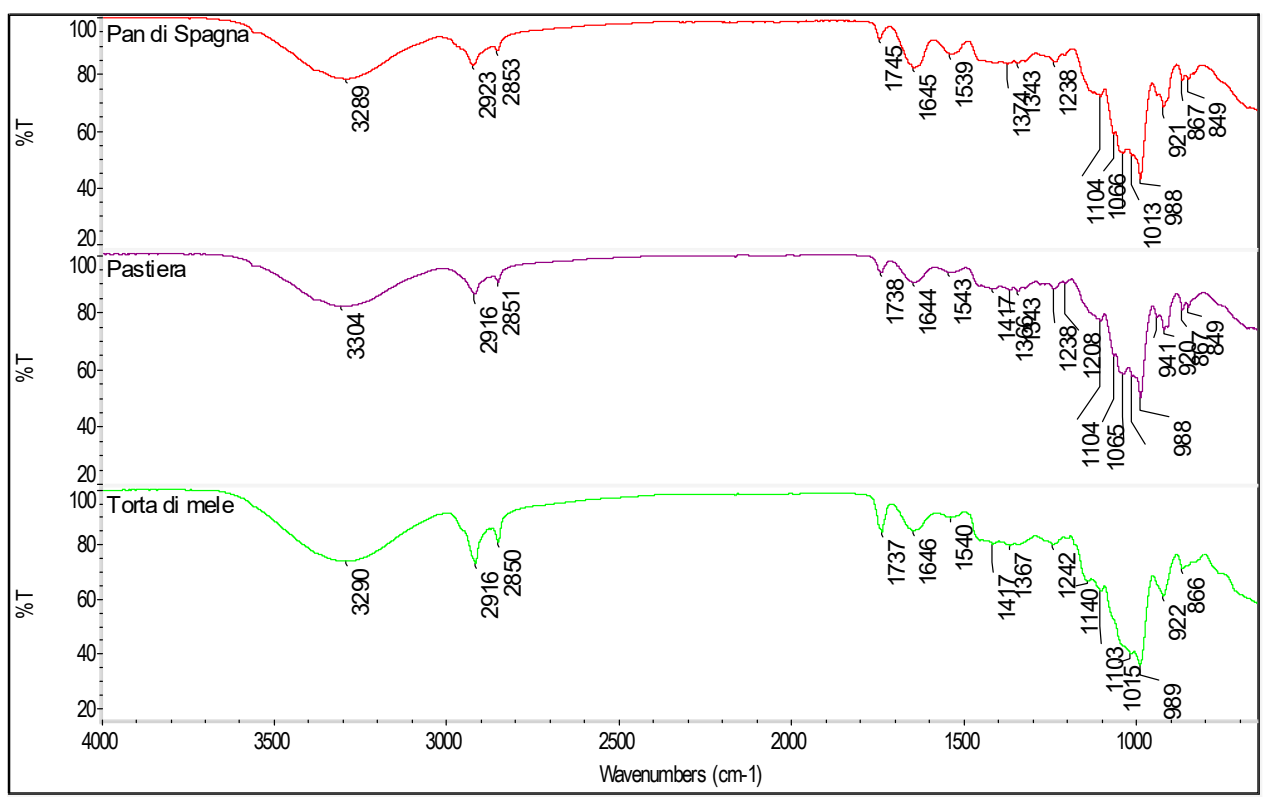

Figure 4. Averaged FTIR spectra of Desserts (Pan di Spagna, Torta di mele, Pastiera) in the mid-infrared region $\left(4000-650 \mathrm{~cm}^{-1}\right)$.

Concerning the First courses, the peaks observed (Figure 1) at 1015, 1077, and $1149 \mathrm{~cm}^{-1}$ in all three dishes are related to the $\mathrm{C}-\mathrm{O}-\mathrm{C}$ stretching and $\mathrm{CO}(-\mathrm{COH})$ stretching of starch [39]. Li et al. [39] describes how these three peaks were observed to have increased significantly in gluten proteins of cooked noodles. This reflects the presence of residual starch in the samples, and it is potentially induced by the increased connectivity between proteins and starch during cooking. The peak found at $850 \mathrm{~cm}^{-1}$ is assigned to the aromatic C-H out-of-plane deformation, and the peak at $759 \mathrm{~cm}^{-1}$ probably corresponds to the S-N stretching mode [40]. Basically, FTIR spectroscopy can also be used to observe changes in the secondary structure of gluten proteins [41,42]. For all First Courses samples, there are peaks at 1645 and $1539 \mathrm{~cm}^{-1}$, which are likely assigned as the amide bands I and II, respectively. Interestingly, Li et al. [42] described how the absorption intensity of the peak at $1655 \mathrm{~cm}^{-1}$ increased during the mixing, resting, and sheeting processes of noodles, whereas it decreased again during cooking. Another typology of FTIR application on pasta, and widely described for cereal-based products [43], is given by Kamil et al. [44], who used FTIR spectroscopy as a tool for detecting the adulteration of pasta.

As reported in Figure 2, one-dish meals were represented by Gâteau di patate and Parmigiana di melenzane. Concerning potato-based food products, other authors have applied FTIR spectroscopy to potato chips [45-47] and mashed potatoes [48]. In addition, studies of the surface of potato tubers [49] and a potato peel extract [50] or its starch-component [51,52] have been reported. Sivakesava and Irudayaraj, [45] applied Fourier transform infrared photoacoustic spectroscopy (FTIR-PAS) for analyzing potato chips. They monitored the changes in chemical groups related to the fat and oil treatment of home-made chips during heating at $80^{\circ} \mathrm{C}$. The authors showed that when oxidation proceeded, the band near $3005 \mathrm{~cm}^{-1}$ decreased at a rate that was dependent on the nature of the oil used to fry the potato chips. This band was assigned $\mathrm{CH}$ groups at a cis double bond. It disappeared completely with the progressing oxidation in the samples fried for $30 \mathrm{~s}$, suggesting isomerisation of the oils in the potato chips. Under oxidative conditions, a peculiar behavior was observed. There was a decrease of the band of the ester carbonyl functional group of the triglycerides $\left(1749 \mathrm{~cm}^{-1}\right)$. In addition, a decrease of the bands from the bending vibrations of the $\mathrm{CH}_{2}$ and $\mathrm{CH}_{3}$ aliphatic groups (1464 and $1375 \mathrm{~cm}^{-1}$ ) was observed. Against the intuition, there was no change of the bands at 1239 and $1160 \mathrm{~cm}^{-1}$ during the oxidation process. The band at $1099 \mathrm{~cm}^{-1}$, on the other hand, decreased in the presence of oleic acyl groups, while the overlapping of the methylene rocking vibration and the 
out-of plane bending vibration of the cis-disubstituted olefins observed at $721 \mathrm{~cm}^{-1}$ did not change after heating. Concerning the main ingredient of Parmigiana di melanzane, some authors have previously investigated the FTIR application on eggplant peel extract [53].

The only representative of Side dishes is the Carciofi alla romana dish. Concerning artichoke, the main ingredient of Carciofi alla romana, previous studies were focused on artichoke fiber [54], inulin [55], and pectin [56]. Fiore et al. [54] have described the characteristic bands of artichoke fiber, extracted from the stem of a plant. Recently, Ceylan et al. [56] have examined structural features of isolated pectin from different sections of globe artichoke and the industrial waste using FTIR spectroscopy, monitoring the process-dependent structural changes in the molecular structure of pectin molecules. In a recent work of Wang et al. [57], the authors monitored the effects of the heating rate on the fast pyrolysis behavior and on the product distribution of Jerusalem artichoke stalk by using TG-FTIR and Py-GC/MS.

As shown in Figure 3, the peaks observed at 1615, 1539, 1403, 1027, and $815 \mathrm{~cm}^{-1}$ are attributed to the presence of chlorogenic acid and caffeoylquinic acid. Other research groups [58-60] underlined how spectral features in the wavenumber region of $1700-1600 \mathrm{~cm}^{-1}$ and $1300-800 \mathrm{~cm}^{-1}$ have an important role in further characterizing chlorogenic acid isomer composition. In particular, Liang et al. [60] assigned the spectral features of pure chlorogenic acid isomer standards as follows: The peak at $809 \mathrm{~cm}^{-1}$ was attributed to cyclohexane C-O twisting; the peaks at 1120 and $1165 \mathrm{~cm}^{-1}$ are related to cyclohexane $\mathrm{CH}, \mathrm{C}-\mathrm{OH}$ bending, and the phenyl ring bending vibration, respectively; the peak at $1276 \mathrm{~cm}^{-1}$ is due to phenyl $\mathrm{CH}$ rocking vibrations; the peak at $1605 \mathrm{~cm}^{-1}$ was assigned to the phenyl ring stretching; and the peak at $1627 \mathrm{~cm}^{-1}$ was attributed to $C=C$ ethylenic stretching.

In the spectra of the desserts (Figure 4), the region of $1500-900 \mathrm{~cm}^{-1}$ contains the signals of the main monosaccharides, such as fructose and glucose, and disaccharides, such as sucrose. These peaks exhibit high intensities as can be expected. In particular, the region of $900-750 \mathrm{~cm}^{-1}$ corresponds to an abnormal saccharide configuration [61]. Several authors studied the peaks characterizing the sugar fraction [62-64]. In detail, the peak at $921 \mathrm{~cm}^{-1}$ corresponds to the typical bending of C-H of carbohydrates, and the peaks at $1038 \mathrm{~cm}^{-1}$ and $1238 \mathrm{~cm}^{-1}$ correspond to the stretching of $\mathrm{C}-\mathrm{O}$ in the $\mathrm{C}-\mathrm{OH}$ group and to the $\mathrm{C}-\mathrm{C}$ stretching of the carbohydrate structure, respectively. Moreover, the peak at $1104 \mathrm{~cm}^{-1}$ corresponds to the C-O stretching of the C-O-C bond and the peak at $1343 \mathrm{~cm}^{-1}$ is due to the $\mathrm{O}-\mathrm{H}$ bending of the $\mathrm{C}-\mathrm{OH}$ group. The peak at $1417 \mathrm{~cm}^{-1}$ is a combination of the $\mathrm{O}-\mathrm{H}$ bending of the $\mathrm{C}-\mathrm{OH}$ group and the $\mathrm{C}-\mathrm{H}$ bending of the alkenes.

An example of a previous application of FTIR to desserts is given by Syahariza et al. [31], who detected lard adulteration in cake formulations.

\subsection{Multivariate Data Analysis}

In the second part of this study, the FTIR spectra were analyzed using PCA. This approach is commonly utilized for a classification of the data set. It must be admitted that the different dishes investigated in this study can also be discriminated by the naked eye before they are homogenized and lyophilized. However, as an important step towards using FTIR and PCA for the detection of potential fraud, e.g., the use of low quality ingredients in expensive products, we tested if the method is capable of distinguishing between the different dishes. In future work, the discrimination of samples from one type of dish prepared in different ways will be the aim.

In the first step, the full spectra were analyzed. The resulting score plot (not shown) revealed that most of the dish types grouped together. However, the spectra of the Spaghetti alle vongole appeared among the data point cloud of the desserts, and hence an unambiguous classification was not possible. Therefore, we applied the PCA to selected wavenumber ranges in the second step. Considering the $\mathrm{CH} / \mathrm{OH}$ stretching range $\left(4000-2700 \mathrm{~cm}^{-1}\right)$, the resulting score plot revealed a similar behavior as the full spectra. In contrast, feeding the fingerprint region $\left(2000-650 \mathrm{~cm}^{-1}\right)$ into the PCA algorithm leads to a different situation. Figure 5 displays the resulting score plot, in which a clear classification can be observed. Models developed from FTIR spectra using the fingerprint region resulted in models 
with superior discriminative performance. In our analysis, only the first three Principal Components (PCs) were considered as they cover most of the variance of the data set and their loading plots exhibit a reasonable signal-to-noise ratio, which indicated that they are meaningful. It should be noted that the wavenumber ranges were not optimized in any way to avoid the need for a priori knowledge in the data evaluation.

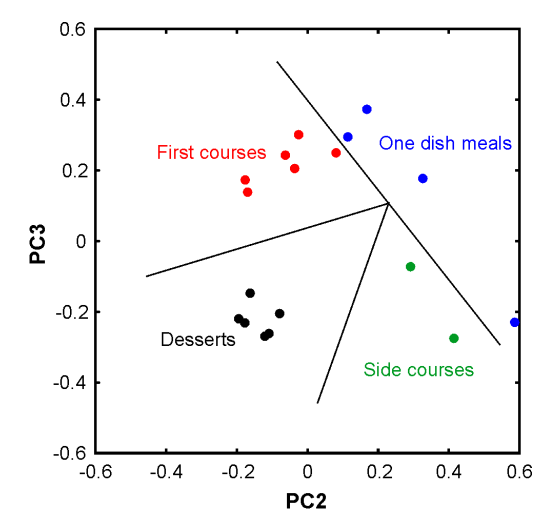

Figure 5. PCA applied to the data set of FTIR spectra feeding the fingerprint region $\left(2000-650 \mathrm{~cm}^{-1}\right)$.

\section{Conclusions}

This study provided spectroscopic fingerprint signatures of the most representative functional groups of some traditional Italian recipes. Numerous peaks, which correspond to functional groups and vibrational modes of the individual ingredients, were identified. Moreover, effects of the preparation procedures, cooking methods, and cooking time were observed. In detail, this study reported an FTIR approach for the discrimination of nine different traditional Italian dishes, which can be clearly grouped into four subtypes using principal component analysis (PCA). According to their characteristic FTIR signatures, an unambiguous classification of the food groups was possible, enabled by their distinctive ingredients. This underlines that FTIR spectroscopy in the fingerprint region combined with chemometric data analysis in terms of PCA represents a powerful tool for the reliable discrimination between composite dishes.

This is a very promising outcome as it provides further support for our hypothesis that the combination of FTIR and multivariate data analysis is a suitable means of product discrimination, a tool for continuous product quality monitoring in the food processing industry, and a method for the detection and investigation of fraud. Since the rather simple PCA algorithm already shows a satisfactory performance, other, more complex approaches, such as artificial neural networks (ANN), will likely perform even better.

The mid-term aim of our research is to utilize spectroscopic data sets and the information extracted from them by multivariate methods as new indicators of food quality. This approach will certainly not be limited to food as it is easily transferable to other sectors.

Author Contributions: A.D., J.K., M.L. and L.M. have conceived the work and wrote the manuscript. All authors have carried out the experimental study and analyzed the data. All authors have made a substantial contribution to revise the work, and approved it for publication.

Funding: This work was supported by the project QUALIFU-SIAGRO (MiPAAF D.M. 2087/7303/09, 28/01/2009).

Conflicts of Interest: The authors declare no conflict of interest.

\section{References}

1. Jacobs, D.R., Jr.; Tapsell, L.C. Food, not nutrients, is the fundamental unit in nutrition. Nutr. Rev. 2007, 65, 439-450. [CrossRef] [PubMed]

2. Capatti, A.; Montanari, M. La Cucina Italiana. Storia di Una Cultura, 7th ed.; Editori Laterza: Bari, Italy, 2006. 
3. Cordonier Segger, M.C.; Phillips, F. Indigenous Traditional Knowledge for Sustainable Development: The Biodiversity Convention and Plant Treaty Regimes. J. For. Res. 2015, 20, 430-437. [CrossRef]

4. Camilli, E.; Lisciani, S.; Marconi, S.; Gabrielli, P.; Durazzo, A.; Gambelli, L.; Aguzzi, A.; Lucarini, M.; Turrini, A.; Zanoni, B.; et al. Some traditional Mediterranean dishes in the Italian diet. In Proceedings of the 1st World Conference on the Mediterranean diet: Revitalizing the Mediterranean Diet, Milan, Italy, 6-8 July 2016.

5. Lombardi-Boccia, G.; Marletta, L. La Carne Bovina nella Gastronomia Italiana. Valore Nutritivo di Alcune Ricette Tipiche; Istituto Nazionale di Ricerca per gli Alimenti e la Nutrizione: Rome, Italy, 2008.

6. Vasilopoulou, E.; Trichopoulou, A. The micronutrient content of traditional Greek foods. Med. J. Nutr. Metab. 2009, 2, 97-102. [CrossRef]

7. Ramdath, D.D.; Hilaire, D.G.; Brambilla, A.; Sharma, S. Nutritional composition of commonly consumed composite dishes in Trinidad. Int. J. Food Sci. Nutr. 2011, 62, 34-46. [CrossRef] [PubMed]

8. Costa, H.S.; Vasilopoulou, E.; Trichopoulou, A.; Finglas, P. New nutritional data on traditional foods for European food composition databases. Eur. J. Clin. Nutr. 2010, 64, 73-81. [CrossRef] [PubMed]

9. Costa, H.S.; Albuquerque, T.G.; Sanches-Silva, A.; Vasilopoulou, E.; Trichopoulou, A.; D'Antuono, L.F.; Alexieva, I.; Boyko, N.; Costea, C.; Fedosova, K.; et al. New nutritional composition data on selected traditional foods consumed in Black Sea Area countries. J. Sci. Food Agric. 2013, 93, 3524-3534. [CrossRef] [PubMed]

10. Durazzo, A.; Lisciani, S.; Camilli, E.; Gabrielli, P.; Marconi, S.; Gambelli, L.; Aguzzi, A.; Lucarini, M.; Maiani, G.; Casale, G.; et al. Nutritional composition and antioxidant properties of traditional Italian dishes. Food Chem. 2017, 218, 70-77. [CrossRef] [PubMed]

11. Guerrero, L.; Guàrdia, M.D.; Xicola, J.; Verbeke, W.; Vanhonacker, F.; Zakowska-Biemans, S.; Sajdakowska, M.; Sulmont-Rossé, C.; Issanchou, S.; Contel, M.; et al. Consumer-driven definition of traditional food products and innovation in traditional foods. A qualitative cross-cultural study. Appetite 2009, 52, 345-354. [CrossRef] [PubMed]

12. Romano, R.; Santini, A.; Le Grottaglie, L.; Manzo, N.; Visconti, A.; Ritieni, A. Identification markers based on fatty acid composition to differenziate between roasted Arabica and Canephora (Robusta) coffee varieties in mixtures. J. Food Compos Anal. 2014, 35, 1-9. [CrossRef]

13. Durazzo, A.; Kiefer, J.; Lucarini, M.; Marconi, S.; Lisciani, S.; Camilli, E.; Gambelli, L.; Gabrielli, P.; Aguzzi, A.; Finotti, E.; et al. An innovative and integrated food research approach: Spectroscopy applications to milk and a case study of a milk-based dish. Braz. J. Anal. Chem. 2018, 5, 12-27. [CrossRef]

14. Diem, M. Introduction to Modern Vibrational Spectroscopy; Wiley: New York, NY, USA, 1993.

15. Lucarini, M.; Durazzo, A.; Sánchez Del Pulgar, J.; Gabrielli, P.; Lombardi-Boccia, G. Determination of fatty acid content in meat and meat products: The FTIR-ATR approach. Food Chem. 2018, 267, 223-230. [CrossRef] [PubMed]

16. Nesakumar, N.; Baskar, C.; Kesavan, S.; Rayappan, J.B.B.; Alwarappan, S. Analysis of Moisture Content in Beetroot using Fourier Transform Infrared Spectroscopy and by Principal Component Analysis. Sci. Rep. 2018, 8, 7996. [CrossRef] [PubMed]

17. De Girolamo, A.; Cervellieri, S.; Cortese, M.; Porricelli, A.C.R.; Pascale, M.; Longobardi, F.; von Holst, C.; Ciaccheri, L.; Lippolis, V. Fourier transform near-infrared and mid-infrared spectroscopy as efficient tools for rapid screening of deoxynivalenol contamination in wheat bran. J. Sci. Food Agric. 2018. [CrossRef] [PubMed]

18. Li, Z.; Suslick, K.S. Portable optoelectronic nose for monitoring meat freshness. ACS Sens. 2016, 1, $1330-1335$. [CrossRef]

19. Christou, C.; Agapiou, A.; Kokkinofta, R. Use of FTIR spectroscopy and chemometrics for the classification of carobs origin. J. Adv. Res. 2017, 10, 1-8. [CrossRef] [PubMed]

20. Manfredi, M.; Robotti, E.; Quasso, F.; Mazzucco, E.; Calabrese, G.; Marengo, E. Fast classification of hazelnut cultivars through portable infrared spectroscopy and chemometrics. Spectrochim. Acta A Mol. Biomol. Spectrosc. 2018, 189, 427-435. [CrossRef] [PubMed]

21. Cai, J.-X.; Wang, Y.F.; Xi, X.-G.; Li, H.; Wei, X.L. Using FTIR spectra and pattern recognition for discrimination of tea varieties. Int. J. Biol. Macromol. 2015, 78, 439-446. [CrossRef] [PubMed] 
22. Lee, B.-J.; Zhou, Y.; Lee, J.S.; Shin, B.K.; Seo, J.-A.; Lee, D.; Kim, Y.S.; Choi, H.K. Discrimination and prediction of the origin of Chinese and Korean soybeans using Fourier transform infrared spectrometry (FT-IR) with multivariate statistical analysis. PLoS ONE 2018, 13, e0196315. [CrossRef] [PubMed]

23. Alamprese, C.; Casiraghi, E. Application of FT-NIR and FT-IR spectroscopy to fish fillet authentication. LWT Food Sci. Technol. 2015, 63, 720-725. [CrossRef]

24. Jiménez-Sotelo, P.; Hernández-Martínez, M.; Osorio-Revilla, G.; Meza-Márquez, O.G.; García-Ochoa, F.; Gallardo-Velázquez, T. Use of ATR-FTIR spectroscopy coupled with chemometrics for the authentication of avocado oil in ternary mixtures with sunflower and soybean oils. Food Addit. Contam. Part A Chem. Anal. Control Expos. Risk Assess. 2016, 33, 1105-1115. [CrossRef] [PubMed]

25. Rodriguez-Saona, L.E.; Allendorf, M.E. Use of FTIR for Rapid Authentication and Detection of Adulteration of Food. Annu. Rev. Food Sci. Technol. 2011, 2, 467-483. [CrossRef] [PubMed]

26. Granato, D.; de Araứjo, V.M.; Jarvis, B. Observations on the use of statistical methods in Food Science and Technology. Food Res. Int. 2014, 55, 137-149. [CrossRef]

27. Otto, M. Chemometrics: Statistics and Computer Application in Analytical Chemistry, 3rd ed.; Wiley: New York, NY, USA, 2016; ISBN 978-3-527-34097-2.

28. Kumar, N.; Bansal, A.; Sarma, G.S.; Rawal, R.K. Chemometrics tools used in analytical chemistry: An overview. Talanta 2014, 123, 186-199. [CrossRef] [PubMed]

29. Karoui, R.; Downey, G.; Blecker, C. Midinfrared spectroscopy coupled with chemometrics: A tool for the analysis of intact food systems and the exploration of their molecular structure-quality relationships-A review. Chem. Rev. 2010, 110, 6144-6168. [CrossRef] [PubMed]

30. Franca, A.S.; Oliveira, L.S. Potential uses of fourier transform infrared spectroscopy (FTIR) in food processing and engineering. In Food Engineering; Siegler, B.C., Ed.; Nova Science Publishers Inc.: Hauppauge, NY, USA, 2011; ISBN 978-1-61728-913-2.

31. Syahariza, Z.A.; Che Man, Y.B.; Selamat, J.; Bakar, J. Detection of lard adulteration in cake formulation by Fourier transform infrared (FTIR) spectroscopy. Food Chem. 2005, 92, 365-371. [CrossRef]

32. Shaikh, T.H.; Mahesar, S.A.; Shah, S.N.; Kori, A.H.; Sherazi, S.T.H.; Lakho, S.A. FTIR spectroscopy combined with chemometric: A versatile tool for quality evaluation of fried vermicelli. Ukrainian Food J. 2017, 6, 61-76. [CrossRef]

33. Durazzo, A.; Camilli, E.; Marconi, S.; Lisciani, S.; Gabrielli, P.; Gambelli, L.; Aguzzi, A.; Lucarini, M.; Kiefer, J.; Marletta, L. Nutritional composition and dietary intake of composite dishes traditionally consumed in Italy. J. Food Compos. Anal. 2018. under review.

34. Finglas, P.M.; Berry, R.; Astley, S. Assessing and improving the quality of food composition databases for nutrition and health applications in Europe: The contribution of EuroFIR. Adv. Nutr. 2014, 5, 608-614. [CrossRef]

35. Greenfield, H.; Southgate, D.A.T. Food composition data. In Production, Management, and Use, 2nd ed.; Food and Agriculture Organization of the United Nations: Rome, Italy, 2003.

36. Abdi, H.; Williams, L.J. Principal component analysis, Wiley Interdiscip. Rev. Comput. Stat. 2010, 2, $433-459$.

37. Yap, K.Y.L.; Chan, S.Y.; Lim, C.S. Infrared-based protocol for the identification and categorisation of ginseng and its products. Food Res. Int. 2007, 40, 643-652. [CrossRef]

38. Smith, B.C. Infrared Spectra Interpretation. A Systematic Approach, 1st ed.; CRC Press LLC: Boca Raton, FL, USA, 1999.

39. Li, W.; Dobraszczyk, B.J.; Dias, A.; Gil, A.M. Polymer conformation structure of wheat proteins and gluten subfractions revealed by ATR-FTIR. Cereal Chem. 2006, 83, 407-410. [CrossRef]

40. Deepa, M.; Agnihotry, S.A.; Gupta, D.; Chandra, R. Ion-pairing Effects and Ion-solvent-polymer Interactions in Lin(CF3SO2)2-PC-PMMA Electrolytes: A FTIR Study. Electrochim. Acta 2004, 49, 373-383. [CrossRef]

41. Bock, J.E.; West, R.; Iametti, S.; Bonomi, F.; Marengo, M.; Seetharaman, K. Gluten structural evolution during pasta processing of refined and whole wheat pasta from hard white winter wheat: The influence of mixing, drying, and cooking. Cereal Chem. 2015, 92, 460-465. [CrossRef]

42. Li, Y.; Chen, Y.; Li, S.; Gao, A.; Dong, S. Structural changes of proteins in fresh noodles during their processing. Int. J. Food Prop. 2017, 20, S202-S213. [CrossRef]

43. Ambrose, A.; Cho, B.K. A Review of Technologies for Detection and Measurement of Adulterants in Cereals and Cereal Products. J. Biosyst. Eng. 2014, 39, 357-365. [CrossRef]

44. Kamil, M.M.; Hussien, A.M.S.; Ragab, G.H.; Khalil, S.K.H. Detecting Adulteration of Durum Wheat Pasta by FT-IR Spectroscopy. J. Am. Sci. 2011, 7, 573-578. 
45. Sivakesava, S.; Irudayaraj, J. Analysis of potato chips using FTIR photoacoustic spectroscopy. J. Sci. Food Agric. 2000, 80, 1805-1810. [CrossRef]

46. Rein, A.; Rodriguez-Saona, L.E. Measurement of Acrylamide in Potato Chips by Portable FTIR Analyzers; Application Note; Agilent Technologies, Inc.: Santa Clara, CA, USA, 2013.

47. Ayvaz, H.; Rodriguez-Saona, L.E. Application of Handheld and Portable Spectrometers for Screening Acrylamide Content in Commercial Potato Chips. Food Chem. 2015, 174, 154-162. [CrossRef] [PubMed]

48. Dankar, I.; Haddarah, A.; Omar, F.E.L.; Pujolà, M.; Sepulcre, F. Characterization of food additive-potato starch complexes by FTIR and X-ray diffraction. Food Chem. 2018, 260, 7-12. [CrossRef] [PubMed]

49. Erukhimovitch, V.; Tsror (Lahkim), L.; Hazanovsky, M.; Huleihel, M. Direct identification of potato's fungal phyto-pathogens by Fourier-transform infrared (FTIR) microscopy. J. Spectrosc. 2010, 24, 609-619. [CrossRef]

50. Ibrahim, T.H.; Chehade, Y.; Abouzour, M. Corrosion Inhibition of Mild Steel using Potato Peel Extract in 2M HCl Solution. Int. J. Electrochem. Sci. 2011, 6, 6542-6556.

51. Bartosova, A.; Soldán, M.; Sirotiak, M.; Blinová, L.; Michaliková, A. Application of FTIR-ATR spectroscopy for determination of glucose in hydrolysates of selected starches. Res. Pap. Fac. Mater. Sci. Technol. Slovak Univ. Technol. 2013, 21, 116-121.

52. Abdullah, A.H.D.; Chalimah, S.; Primadona, I.; Hanantyo, M.H.G. Physical and chemical properties of corn, cassava, and potato starchs. IOP Conf. Ser. Earth Environ. Sci. 2018, 160, 012003. [CrossRef]

53. Darvanjooghi, M.H.K.; Davoodi, S.M.; Dursun, A.I.; Ehsani, M.R.; Karimpour, I.; Ameri, E. Application of treated eggplant peel as a low-cost adsorbent for water treatment toward elimination of $\mathrm{Pb}^{2+}$ : Kinetic modeling and isotherm study. Adsorpt. Sci. Technol. 2018, 36, 1112-1143. [CrossRef]

54. Fiore, V.; Valenza, A.; Di Bella, G. Artichoke (Cynara scolymus L.) fibres as potential reinforcement of composite structures. Compos. Sci. Technol. 2011, 71, 1138-1144. [CrossRef]

55. López-Molina, D.; Navarro-Martínez, M.D.; Rojas Melgarejo, F.; Hiner, A.N.; Chazarra, S.; Rodríguez-López, J.N. Molecular properties and prebiotic effect of inulin obtained from artichoke (Cynara scolymus L.). Phytochemistry 2005, 66, 1476-1484. [CrossRef] [PubMed]

56. Ceylan, C.; Bayraktar, O.; Atci, E.; Sarrafi, S. Extraction and characterization of pectin from fresh globe artichoke and canned artichoke waste. GIDA J. Food 2017, 42, 568-576. [CrossRef]

57. Wang, B.; Xu, F.; Zong, P.; Zhang, J.; Tian, Y.; Qiao, Y. Effects of heating rate on fast pyrolysis behavior and product distribution of Jerusalem artichoke stalk by using TG-FTIR and Py-GC/MS. Renew. Energy 2019, 132, 486-496. [CrossRef]

58. Ribeiro, J.S.; Salva, T.J.; Ferreira, M.M.C. Chemometric studies for quality control of processed Brazilian coffees using drift. J. Food Qual. 2010, 33, 212-227. [CrossRef]

59. Nallamuthu, I.; Devi, A.; Khanum, F. Chlorogenic acid loaded chitosan nanoparticles with sustained release property, retained antioxidant activity and enhanced bioavailability. Asian J. Pharm. Sci. 2015, 10, $203-211$. [CrossRef]

60. Liang, N.; Lu, X.; Hu, Y.; Kitts, D.D. Application of Attenuated Total Reflectance-Fourier Transformed Infrared (ATR-FTIR) Spectroscopy to determine the Chlorogenic acid isomer profile and antioxidant capacity of coffee Beans. J. Agric. Food Chem. 2016, 64, 681-689. [CrossRef] [PubMed]

61. Tulchinsky, V.M.; Zurabiab, S.F.; Asankozhoev, K.A.; Kogan, G.A.; Khorlin, A.V. Study of the infrared spectra of oligosaccharides in the region 1000-400 $\mathrm{cm}^{-1}$. Carbohydr. Res. 1976, 51, 1-8.

62. Bureau, S.; Ruizb, D.; Reich, M.; Gouble, B.; Bertrand, D.; Audergon, J.M.; Renard, C.M.G.C. Application of ATR-FTIR for a rapid and simultaneous determination of sugars and organic acids in apricot fruit. Food Chem. 2009, 115, 1133-1140. [CrossRef]

63. Velázquez, T.G.; Revilla, G.O.; Loa, M.Z.; Espinoza, Y.R. Application of FTIR-HATR spectroscopy and multivariate analysis to the quantification of adulterants in Mexican honeys. Food Res. Int. 2009, 42, 313-318. [CrossRef]

64. Anjos, O.; Campos, M.G.; Ruiz, P.C.; Antunes, P. Application of FTIR-ATR spectroscopy to the quantification of sugar in honey. Food Chem. 2015, 169, 218-223. [CrossRef] [PubMed]

(C) 2018 by the authors. Licensee MDPI, Basel, Switzerland. This article is an open access article distributed under the terms and conditions of the Creative Commons Attribution (CC BY) license (http:/ / creativecommons.org/licenses/by/4.0/). 